\title{
The Motive of Vyšehrad as a Wireless Signature Tune on the Waves of Praha Radio Station and in Feature Films
}

\section{Ivan Klimeš}

One sometimes hears the term, second life, used to describe the situation of a certain phenomenon (or person, or event), already removed in time from its original historical context, and yet present, in one way or another, in subsequent periods. In the case treated here, though, the essence of the matter might perhaps be better captured by the expression, another life. As follows from the title of this text, it will focus on a fragment of an art work separated from the original whole, and grafted onto a different context, or more precisely, two different contexts. This seemingly simple, indeed mechanical operation, is accompanied by widely varied and comparatively intricate since never completed semantic goings-on, and the case of the well-known Smetana musical motive happens to be particularly transparent in the given sense. At the same time, one can perhaps aspire to catching a glimpse, through this instance of another life, of a more general feature of modern culture (musical culture included), for which a historically novel environment has been generated with the emergence of new media and communication technologies.

However, let's start with facts. Wireless broadcasting began in Czechoslovakia on $18^{\text {th }}$ May, 1923, and the two-measure motive of Vyšehrad became the signature tune of the Praha radio station in the year of the tenth anniversary of the existence of Radiojournal company, that is, in 1933. Up till then the radio stations, Praha; Brno; Moravská Ostrava; Bratislava; and Košice used as their broadcasting interval signature the sound of the standard tuning A note (one sustained plus five staccato tones). ${ }^{1}$ The practice pursued in that respect by different European broadcasters was extremely varied. For instance, a survey dating from 1933 which was subsequently re-published periodically with several weeks between the individual issues, documents that all Hungarian stations used an unspecified chimed tune; Polish stations differed from one another, with Warsaw using a combination of the Morse code and a piano tune, Lodz a gong with glockenspiel, Cracow

1 “Seznam stanic", Radiojournal 11, no. 39 (September 23, 1933): 14. 
and Lwow bell chimes, Poznan clock ticking, bell and trumpet, and Vilnius the sounds of the cuckoo. Bird voices were popular with French stations: for instance, Paris used cock's crow as its signature tune (voice of the Gallic cock); while the Italian stations, Genoa, Milan, Turin, Trieste, Palermo and Florence, used the nightingale's song. British stations, as well as Austrian ones, would mostly prefer clock or metronome ticking, whereas German stations showed unequivocal preference for melodic signatures. ${ }^{2}$

Clearly, however, the early 1930s witnessed the rise to popularity of radio signature tune whose message would accentuate the musical, or in a broader sense, cultural-historical symbolism of a given place: thus for instance, Munich Radio introduced, on $1^{\text {st }}$ July, 1933, as its signature the bell chimes from Parsifal; ${ }^{3}$ Nuremberg, a motive from Die Meistersinger von Nürnberg; while Dresden and Leipzig coupled clock ticking with the notes, B-A-C-H. ${ }^{4}$ For their part, the stations at Heilsberg, Königsberg and Danzig, grouped in the OstmarkenRundfunk company, replaced their previous glockenspiel chord by the incipit of the Mazurian song, Wild flutet der See. ${ }^{5}$ In late 1933, new "interval signatures" were likewise given to the northern German radio stations in Kiel and Flensburg: namely, the melody of the song, Schleswig-Holstein, stammverwandt; Radio Bremen came up with the melody of the song, Wo die Nordseewellen trecken an den Strand; and Hamburg, as the principal broadcaster in that group, contributed a melody from Derfliegende Holländer. ${ }^{6}$ A parallel step was made by Belgian radio stations: the Brussels French-language station used as its interval signature three notes from a tune by A.-E.-M. Grétry, and closed its daily broadcast down with the national anthem, whereas the Flemish-language station's interval signature was the carillon version of a Flemish song by Peter Benoit, a composer who had been involved in the second half of the $19^{\text {th }}$ century in the Vlaamse Beweging, and closed down with the Flemish national song, The Flemish Lion. ${ }^{7}$ An equally convincing proof of the localizing function of this type of signature tune is provided by the case of the French station, Radio-Nîmes, which chose at the end of the year 1933 as its signature tune the ancient local song, $A$ la fond $d e$ Nîmes, sung by a choir in the Provençal dialect. ${ }^{8} \mathrm{~A}$ similar option was pondered in 1933 by the Viennese broadcaster, Ravag, which intended to use the opening bars of the Strauss Blue Danube waltz, but eventually gave up its plans to

\footnotetext{
${ }^{2}$ Ibid. (List of interval signatures from 1932, see Appendix.)

3 “Nové přestávkové znamení v Mnichově”, Radiojournal 11, no. 29 (July 15, 1933): 5.

4 "Seznam stanic", Radiojournal 11, no. 31 (July 29, 1933): XXXIX.

5 “Nové znamení v Heilsbergu”, Radiojournal 11, no. 31 (July 29, 1933): IV.

6 “Nová přestávková znamení NORAG”, Radiojournal 11, no. 45 (November 4, 1933): 5.

7 “Belgický rozhlas má nové přestávkové znamení", Radiojournal 11, no. 41 (October 7, 1933): 14.

8 "Přestávková znamení ve Francii”, Radiojournal 11, no. 51 (December 16, 1933): 21.
} 
introduce a new "interval signature", arguing that the interminable repetition of those opening bars would soon prove bothersome to listeners and would in the end harm the popular waltz melody. ${ }^{9}$

As all of this shows, the step taken by Radiojournal fell within a broader trend which was then taking hold all across the young world of the wireless, and which by all accounts was also in tune, to some extent at least, with the upsurge of nationalism accompanying the increasingly complex political and economic situation of Europe in the 1930s. Likewise corresponding with it, after all, was the way in which the populations in more than a few countries, and indeed various nations as institutions as well, responded to the emergence of talking film at the turn of the 1920s and 1930s, a phenomenon which amounted to an unprecedented - on such a scale at least - intrusion of foreign language onto their home language ground. This entailed protests in newspaper columns, public demonstrations,${ }^{10}$ imposition of film import limits and restrictions on the circulation of original language versions, plus in certain cases legal provisions enforcing dubbing of foreign-language films (Italy). ${ }^{11}$ Thus young technological media with a globalizing potential soon became a ground on which could be observed certain processes which later came to be known as "glocalizational". ${ }^{12}$

The idea to introduce as the signature tune of Praha radio station the opening four chords of Smetana's symphonic poem, Vyšehrad, was first raised by the director of Radiojournal's music section, Karel Boleslav Jirák. ${ }^{13}$ His proposal does

\footnotetext{
9 “Budíček ve Vídni zůstane”, Radiojournal 11, no. 29 (July 15, 1933): 5.

${ }^{10}$ These street protests were particularly stormy in Prague, where they even led to a temporary ban on the screening of German films in the original language version. Cf. Nancy Meriwether Wingfield, "When Film Became National: "Talkies" and the Anti-German Demonstrations of 1930 in Prague", Austrian History Yearbook 29, no. 1 (1998): 113-138; Dagmar Moravcová, Československo, Némecko a evropská hnutí 1929-1932 ([Prague]: ISE, 2001), 198-216.

${ }^{11}$ For instance, the Czechoslovak state regulated the distribution of films dubbed in German in the domestic cinema network: the screening of those versions was thus authorized only in communities inhabited by more than 50 percent of native German speakers. These measures did not apply to foreign films in other languages. In Mussolini's Italy, the arrival of talking films entailed, still in the year 1930, the issue of a law forbidding the screening of foreign-language films in their original versions, and made dubbing summarily compulsory. Cf. Nataša Durovičová, "Local Ghosts: Dubbing Bodies in Early Sound Cinema", in Il film e i suoi multipli / Film and its multiples, ed. Anna Antonini (Udine: Forum, 2003), 83-98 (Czech edition including a supplement on the situation in Czechoslovakia, see Nataša Ďurovičová, "Místní suplenti. Dabing na úsvitu éry zvukového filmu”, Iluminace 17, no. 2 (2005): 5-29); Ivan Klimeš, "Multiple-language Versions of Czech Films and the Film Industry in Czechoslovakia in the 1930s", Cinema EO Cie, no. 4 (Spring 2004): 89-101.

${ }^{12}$ The term, "glocalization", which emerged as the amalgam of "globalization" and "localization", relates to the interrelatedness of the globalizing and localizing pressures being faced by modern society. Cf. Zygmunt Bauman, Globalizace. Dissledky pro člověka (Prague: Mladá fronta, 2000), 86. ${ }^{13}$ Cf. Vladimír Dvořák, “Co víte o znělkách čs. rozhlasu?”, Náš rozhlas 13, no. 50 (December 8, 1946): 5. On K. B. Jirák's tenure at Czechoslovak Radio, cf. Milan Kuna, Exulantem proti své vưli. Život
} 
not seem to have met with adverse response or to have been countered by any competitive alternatives; at least no sign of debate on this subject penetrated into the pages of specialized radio and music press. ${ }^{14}$

The choice was doubtless absolutely brilliant. Here was a brief melodious motive, which was widely familiar to the general public, and which came from a piece of music enjoying quite exceptional respect, and last but not least, a motive which actually related to a dual source: as part of the symphonic poem, Vyšehrad, it also belonged in the cycle, My Fatherland, an element particularly relevant to its semantic potential. Also most auspiciously in this respect, the musical fragment in question comes from the beginning of the composition, not a quotation from its middle; of course, it is easily identified as such by the listener, which in its turn stimulates the anticipation of continuance, an element adding up to the virtual topicalization of the composition's "lost" remaining part. Further symbolic potential of this beginning resides in the "story" of Vyšehrad. Smetana's symphonic poem uses the language of music to describe the "story" of Czech statehood; thus the introductory harp motive which opens this "story" can also be related explicitly to the dawn of the Czech state. The motive, moreover, was furnished by a composer who enjoyed an unequivocally dominant status in the cultural mindset of the Czech public; and lastly, this motive was also likely to fulfill the function of an element of specific localization, where it was viable as a symbol of Prague, as well as of Czech statehood, offering on the plane of reception the option of switching between the two semantic alternatives, or even assuming both meanings at once. A non-negligible part was definitely also played there by technological aspects: radio technologies (recording and broadcasting alike), in the early 1930s still fairly rudimentary, had something of a problem with the handling of the sound of certain symphony orchestra instruments. Not ranking among those, the harp proved an exceptionally radiogenic instrument. ${ }^{15}$

a dílo Karla Boleslava Jiráka (Prague: Editio Baerenreiter, 2003), 99-106, 111-117.

${ }^{14}$ Other Czechoslovak Radio stations likewise set out on the road of introducing melodious interval signature tunes with symbolic charge. For instance, the station Praha II, Mělník, employed from January 1934 as its signature tune the introductory flourish from Josef Suk's ceremonial march for the Sokol association, Towards New Life, performed there by solo trumpet. Cf. Dvořák, "Co víte o znělkách", 5. The Brno station eventually opted for the popular song, Moravia, Moravia, in the key of $\mathrm{C}$ sharp major, performed on electric piano; it launched the new signature tune on the air in late 1935. Cf. Slk, “O brněnské znělce”, Radiojournal 13, no. 39 (September 28, 1935): 4.

${ }^{15}$ In the 1920s and during the first half of the 1930s it was widely believed that the new medium would call into life a new genre in music: namely, that of radio music. For instance, music director of Czechoslovak Radio's Brno station Karel Vetterl wrote in 1929: "The sonic environment of the wireless contains a thoroughly autonomous element of musical style, one which has enough strength to open up the way for an autonomous musical production." Quoted after A. J. Patzaková, Pronich deset let ceskoslovenského rozblasu (Prague: Radiojournal, 1935, 285. The ideas of what such autonomous radio music should be like, were influenced among other things by the limitations of the radio 
That it was exactly the above-mentioned dual symbolism which played a key role in the choice of the musical motive is attested to by the date of the signature tune's first airing which became immediately linked not, as might have been expected, with the tenth anniversary of the existence of Radiojournal, but rather more significantly, with the $15^{\text {th }}$ anniversary of the birth of the Czechoslovak Republic. The motive of Smetana's Vyšehrad was first featured as the signature tune of Praha station on $28^{\text {th }}$ October, 1933, in an act whose symbolism was still enhanced by its coordination with an official ceremony involving the presence of the Republic's President. After all, let's recall the way the introduction of the signature tune was presented by the Radiojournal weekly:

At the moment of the Prague station speaker's announcing, on $28^{\text {th }}$ October, 1933, to all of the Republic's regions, the arrival of the President on the scene of the march-past of this country's military units, Czechoslovak Radio started its broadcast with the interval signature tune which will from now on make our stations readily recognizable among many European wireless stations, even without prior consultation of the key to wavelengths. The Czechoslovak Radio's interval signature tune is constituted by the first two bars of Smetana's majestic symphonic poem, Vyšehrad, whose tender and solemn harp chords are reminiscent of the sound of Lumir's ancient prophetic lyre. Starting from the day of the $15^{\text {th }}$ anniversary of the existence of our state, this age-old motive will be featured as the signature tune for our wireless programmes. ${ }^{16}$

One of Radiojournal's subsequent issues then marked the introduction of the signature tune by a collage on its cover, assembled from the notation of the four chords in question, a photograph of harp, and a reproduction of Julius Mařák's painting, Vyšehrad. ${ }^{17}$ Two weeks later, the same magazine returned to the topic once again, by publishing an unsigned article on the history of harp, emphasizing the instrument's exceptional status in the history of Czech music, and observing that it was therefore "thoroughly apposite if we declare ourselves before the rest of the world to be a nation whose mythical bard, Lumír, played the lyre under the majestic walls of Vyšehrad." ${ }^{18}$ In his turn, F. B. (František Bartoš), radio critic for the Prehled rozhlasu magazine pointed out in his own commentary that "in

technology of the day. When, for example, on the occasion of the second edition of the International Music Festival in Venice its organizers called a competition of radiogenic music, the published competition rules contained a list of non-radiogenic tone colours and instrumental combinations, i.e. those found less suitable or unsuitable for radio, including even certain compositional devices (discouraging for instance the use of fast double-bass runs). On that, cf. Veniero Rizzardi (ed.), L'undecisima musa. Nino Rota e i suoi media (Roma: Rai Radiotelevisione Italiana, 2001), 212-213.

16 "Přestávkové znamení československého rozhlasu", Radiojournal 11, no. 45 (November 4, 1933): II.

${ }^{17}$ Radiojournal 11, no. 50 (December 9, 1933): cover.

18 "Něco o harfé", Radiojournal 11, no. 52 (December 23, 1933): 7. 
a certain sense, this signature may even prove binding." ${ }^{19}$ Evidently then, the introduction of the signature tune was accompanied by a good deal of patriotic rhetorics.

As could be seen, the singling out of a properly chosen fragment leaves unaffected its semantic correlations with the original whole. Thus such a fragment carries over to its new context the semantic content of the original work, at once reduced and condensed. The signature tune, in the terminology of its time known as "interval signature", or "interval sign", was destined primarily to make possible the instant identification of a radio station..$^{20}$ In its quality as an interval marker, the signature tune thus found itself in the day-to-day neighbourhood of a wide variety of programmes; with some degree of overstatement (though not too much), this would range from early-morning warmup exercise, through newsreel, political speeches, miscellaneous reports, educative lectures, phonograph record samples, and live broadcasts from concert or theatre performances, sports broadcasts, to serialized readings from books and radio plays. The aforementioned concern felt in Vienna with respect to the use of the Strauss waltz, fearing the listeners' becoming fed up and the motive's being banalized, could by no means be dismissed downright, even though one might rather tend to view the problem in terms of a psychological erosion of the listeners' awareness of the signature tune's semantic background. On no account does that imply, however, that under certain circumstances this semantic background could not be restored to all of its original acuteness and emotive intensity.

This promptly became evident in the course of the turbulent year of 1938, during which radio as the fastest of the news media played a highly significant part vis-a-vis the general public. It served as a channel through which the nation's

\footnotetext{
${ }^{19}$ F. B. [František Bartoš], “K programu Radiojournalu”, Přehled rozhlasu 2, no. 10 (1933): 9.

${ }^{20}$ This entailed an entirely practical effect even in professional international communication between broadcasters. When, for instance, on the night of $14^{\text {th }}-15^{\text {th }}$ January, 1934, radio transmitters were retuned under the provisions of the Lucerne Plan, a move organized through the Union International de Radiodiffusion (U.I.R.) from Brussels, each station was required to present itself by its interval signature, or by a characteristic national tune. The instructions distributed for that purpose to all radio stations in Czechoslovakia by the Ministry of Postal and Telegraph Services, stipulated literally: "The duration of measuring transmission shall be five minutes for each station, within which each station is required to announce its name (in this country, in the Czech language) at intervals of approximately 30 seconds. Spaces in between the announcements shall be filled in by either interval signature, or part of a phonograph recording of a characteristic national composition, in such a manner that the recording in question shall be broadcast repeatedly upon the ending of each announcement." National Archives, Ministry of Postal and Telegraph Services, k. 1427, No. 95/1934, att. to No. 8138/1939; draft ministerial letter to radio broadcasters in the Czechoslovak Republic, Prague, Jan. 4, 1934. For members of radio's technical staff, the signature tune signalled the state of a station's readiness during switchover from one station to another. "O pražské znělce”, Náš rozblas 17, no. 19 (May 7-13, 1939): 6.
} 
political leadership communicated with the citizenry. The proclamation of partial mobilization on $21^{\text {st }}$ May, 1938; the proclamation of full-scale mobilization on $23^{\text {rd }}$ September, 1938; the news of the agreement between Britain, France, Italy and Germany on Germany's territorial claims towards Czechoslovakia of $29^{\text {th }}$ September, 1938; the news of the acceptance of the Munic Agreement by the Czechoslovak government, and on the ensuing demobilization of $30^{\text {th }}$ September, 1938: all of that was listened to by radio audiences against the backdrop of the radio signature tune; no wonder then that the part played in those historic developments by the radio generated corresponding developments on the semantic plane. If the introduction of Vyšehrad as radio signature tune in 1933 had not stirred up any debate, the question of the appropriateness of its further existence cropped up immediately and with full intensity in the sultry atmosphere of the second Czechoslovak Republic, in the final months of the year 1938. The status of Smetana's motive of Vyšehrad as the sonic emblem of Radiojournal's Prague station was upheld in a special radio lecture aired on $20^{\text {th }}$ November, 1938, by the signature tune's "originator", Karel Boleslav Jirák. ${ }^{21}$ The lecture met with an audience response in the form of a flood of letters which can be viewed as a spontaneous poll in its own right. Radiojournal then reportedly received a total of 554 letters, a number which speaks for itself. Of those, 420 writers were stalwart supporters of the existing signature tune, and another 13 were for its keeping, with partial alterations. To those people it symbolized Prague's most ancient historical site, as well as the patriotic pathos of My Fatherland. "Let's not stick our heads into the sand, let's not avoid looking at our past history! To forget is the same as to resign and to give up hope for a brighter future. Let's build a tradition of our own greatness, not one of our defeatism!", one of the letters reportedly exhorted. ${ }^{22}$

The remaining 121 listeners called for a change of the signature tune. Their arguments were diverse, including perhaps even a few rather bizarre ones. Thus for some the existing signature tune was too stark or unmelodious (sic!), while others would deem it much too lyrical, dreamy. Some of the letters even contained specific suggestions of new signature tunes: of those, 19 writers mentioned the song, Čechy krásné, Čechy mé ["Bohemia Beautiful"]; four listeners were for the national anthem, Kde domov müj ["Where Is My Home"]; and four would have been happier with the Sokol movement's march, Lvi silou ["With Lion's Force"]. More cynical listeners favoured such songs as Pryč a pryč je visechno [“All's Lost

${ }^{21}$ The text of Jirák's lecture on the Smetana signature tune has likely been lost, at least as far as can be judged at the current stage in the study of the Czech Radio archives and of the still unresearched fragment of Jirák's literary estate deposited in the Czech Museum of Music, a branch of the National Museum in Prague.

22 “O pražské znělce”, Náš rozhlas 17, no. 19 (May 7-13, 1939): 6. 
and Gone"], or Jak ti chudi o to jmèni prišli [ "How the Paupers Lost All They Had"], or even the dove's cooing, as a symbol of the Czech nation's doveish nature. Someone did not hesitate to suggest operetta tunes from Rudolf Friml's Rose Marie, Oskar Nedbal's Polish Blood, or the then box-office hit by Jára Beneš, Maid Pusy, pandering to the patriotic moods of the day (perhaps that particular writer had in mind a serenade from that opus entitled Praho, mèsto rozkvetlých stráni ["Prague, City of Blossoming Hillsides"]. However, the overwhelming majority of the existing signature tune's detractors cited as their principal argument the fact that to them the tune evoked the sad events of September and October of that year. ${ }^{23}$ In other words, they began to perceive it as a sonic emblem of those developments. It became obvious that the signature tune's symbolic introduction on the day of the $15^{\text {th }}$ anniversary of the founding of Czechoslovakia in fact represented a much more fatal coupling of the Smetana motive with the destiny of the state than anyone would have thought at the time.

Let's now proceed to generalize the above facts. From the viewpoint of the reception of the Smetana motive in its capacity as radio signature tune, three aspects stand out as particularly significant, namely:

a) the shift, or switch-over, from the mode of Sunday-best solemnity to that of day-to-day reality;

b) within the scope of this mode of day-to-day reality there developed what amounted to the virtual identification of the musical emblem with the institution represented by the musical motive in question;

c) as an inseparable part of that institution, the musical emblem was from then on to partake fully in its subsequent fate, which in its turn opened up room for further, secondary emblematization, one which resulted from the role of radio as a medium in the modern history (political, in particular) of the state.

All of these three aspects play an important part in the process of the radio signature tune's transfer to the medium of feature film. When, at the beginning of this text, I noted that the installation of a symbolically significant fragment of a work into new contexts could be accompanied by complex semantic goingson, I had in mind most notably the unpredictability of those contexts which fill a symbol up with topical content. Let's just touch very briefly here upon the actual impact of the extension of the subject matter being dealt with here into the world of feature film. So far the discussion has centered around the motive of Vyšehrad in its capacity of a radio signature tune, as a phenomenon existing in the actual world (that is, in the reality experienced at first hand either by ourselves or by our forebears); now moving into the world of feature film, we leave

${ }^{23}$ Ibid. 
the actual, real world, to enter into an utterly different context: one of a fictional world. At that point, the Smetana musical emblem of the Praha radio station becomes - figuratively speaking - a symbol to the power of two (a symbol of a symbol), with the original semantic structure taking on a new layer which unites with the underlying one.

Of course, the radio signature tune motive in film is part and parcel of the motive of the wireless set at large. To be sure, the latter has assumed a wide variety of functions and meanings in the cinematic production, which are duly reflected in the choice of the type of radio broadcast whose fragment is featured in a given film. There characteristically, the presence of the Smetana signature tune on screen has been limited virtually exclusively to scenes where the wireless provides the backdrop for solemn and dramatic moments of the recent Czech history, most notably set in the years 1938-1945. In a sense, one might even tend to view this in terms of a stereotype which entails a peculiar side-effect: namely, the radio signature tune would appear to become a "signature tune" in its own right of that particular uneasy period. As a rule, in films dealing with those times the wireless set embodies a medium which links the wide world of major historical developments up with the private worlds of individual households, of families threatened by that wider context.

The Smetana radio signature tune was first introduced into a feature film in a most radical way clearly setting the trend for the future, by director Jiří Weiss, immediately after the war's end, quite characteristically in a film drama entitled emotively, Uloupená hranice [The Stolen Border] (1947), dealing with the tragic events that had taken place in the Sudetenland, Czechoslovakia's regions bordering with Germany, in September 1938, before and after the announcement of full-scale mobilization. ${ }^{24}$ The Radiojournal interval signature tune is featured for

\footnotetext{
${ }^{24}$ The very first cinematic treatment of this subject matter can already be found in Jan Bor's drama, Neporažená armáda (1938), shot before the war's outbreak. That film, set in the military academy at Hranice, in Moravia, which was intended as an apotheosis of the Czechoslovak armed forces, and was to demonstrate their preparedness to defend the country, was actually completed after the country's acceptance of the Munich dictate. With the hope of resuscitating the sense of the whole project, it was controversially updated in October 1938, by the shooting of an additional sequence striving to explain, in a somewhat bizarre manner, the purpose of an army in the service of the second Czechoslovak Republic, by then already deprived of its fortified Sudeten borderland. It is not uninteresting that this film still failed in any way to expose the motive of radio as a news-spreading media, nor did it establish any connotational link between the Smetana signature tune and the turbulent historical developments, even though the film's makers otherwise resorted to an abundance of musical symbols, ranging from the late President Masaryk's favourite folk song, $A c h$, synku, synku, through the prophecy of Libuše from Smetana's eponymous opera, to the sounds of which the film reaches its climax. The sequence depicting the mobilization (whether the partial one, of May, or the full-scale one, of September, is unclear), assembled from a series of documentary shots faded with a static picture of the monument of Jan Žižka, is accompanied by stark kettledrum
} 
the first time here at the very beginning, in the titles sequence whose pictorial backdrop is formed by the map of Czechoslovakia with its pre-Munich borders. The film music's composer, Jiři Srnka, enhanced the dramatic impact of the lyrical harp chord by an underlying tremolo delivered by dark-toned strings. There hardly exists a more eloquent example of the use at that time of the Prague Radio signature tune as an emblem of tragic historical events, than here. The signature tune then recurs in several scenes (notably ones located at the police station), invariably pointing to the wireless as a source of the latest news awaited with extreme anxiety and tension. The film's most prominent reference to the motive of radio featuring the Prague signature tune comes in a scene set in a restaurant, during a meeting of fanatic followers of Konrad Henlein. It is there, in this particular scene, that the signature tune becomes the symbol, not of Prague's radio station, but rather of the Czechoslovak state in its darkest moments.

In a crowded inn, the wireless set emits endlessly repeated tones of the Praha radio station's Smetana signature tune.

Kurt, a stalwart pro-Nazi activist, retunes to Leipzig which airs some indifferent German hit tune, but postmaster Johann Zeisler, head of the local Sudeten German Party, intervenes.

Zeisler: Kurt, switch it off!

Kurt: Das ist doch Leipzig.

Zeisler: I know. Switch it off and turn on Prague.

You heard me well. (Kurt does as he is told.)

How do you like this?

Kurt: But then, Prague's mute. (The Smetana signature tune sounds on and on.)

Zeisler: And isn't that wonderful? (He leans to the wireless set, rests his hand on it, and starts talking to it.) Blam-blam! (Heparodies the harp tune.) So what do you have to say, meine lieben Herren Tschechen, about our strong Sudeten German Party? And about our demand of full autonomy? (He straightens up again and turns to the inn's German patrons.) And about our leader Konrad Henlein? And about us not wishing to go on living with you, and our being part and parcel of one great German Reich? The Germans in the room stand up raising their right arms for the Aryan salute, shouting "Sieg Heil!", some mockingly chanting, "Blam-blam!" - among them three old beer-drinking gaffers slamming the tabletop rhythmically with

beats to the rhythm of the Hussite chorale, Ktožjsú boží bojovnici [Ye Who are Warriors of God]. With a high degree of precaution, one could see in this an indication of this film's divergence from the process of topical political emblematization of radio signature tune, or rather, of the said process having been crucially boosted, if not downright sparked off, only by the tragic Munich finale of the dramatic summer of 1938 . 
their fists. Presently the high spirits of all die down as the Smetana signature tune fades out and the wireless emits the voice of an announcer reading out the declaration of full-scale mobilization in defence of the Republic. ${ }^{25}$

The Vyšehrad signature tune was also placed at the very beginning of his screen drama, Neporaženi [The Unconquered] (1956), as a sonic emblem of the traumatic September 1938, by director Jiři Sequens. The first shot after the film's opening titles shows the darkened panorama of a landscape with the sun setting beneath an overcast sky. The appearance of a robust ragged title, SEPTEMBER 1938, is accompanied by the sound of the Smetana signature tune, repeated at regular intervals of several seconds. Only the ensuing slow panoramic pan will reveal that what we are watching now is the skyline of Prague, as there appears in view on the distant horizon the familiar silhouette of Prague Castle towering above the Vltava, "lined" by other distinctive Prague skyline sights: the Petřín lookout tower on the left bank, and the spires of the capitular Church of SS. Peter and Paul at Vyšehrad. In the foreground, jabbing into the sky diagonally over these landmarks on the horizon, are the barrels of heavy-artillery guns which thus, to the accompaniment of the Smetana signature tune, provide a symbolic frame to the picture of historical Prague on the horizon, as the city can be seen from some place on the hill-ridges above Bráník. This symbolic introduction then develops into a sequence showing the September mobilization, announced already in the real setting of homes and streets by the Czechoslovak Radio broadcast introduced by the Smetana signature tune. In Sequens' film, nonetheless, the developments surrounding the Munich Agreement are used merely as a preface to the ensuing description of events which took place six months later: the invasion of what had remained of Czechoslovakia and its occupation by the German Reich after the proclamation in March 1939 of the Protectorate of Bohemia and Moravia. These dark moments of Czech history, too, are signalled here by Czechoslovak Radio: the announcer's repeated call on listeners to stay tuned to their wireless sets is accompanied by the Smetana signature tune, by now already an established harbinger of tragic news for the Czech nation.

Sequens' screen drama, Neporaženi, ranks among rather exceptional cases in that it already projects dramatic work with the Smetana signature tune in the film's script, something which is by no means the rule for other films, and which documents the fact that the "vision" of soundtrack was in most cases shaped only additionally, on the basis of previously shot pictorial material. In contrast to

${ }^{25}$ The dialogues here as well as the description of the sequence in question are drawn from the film itself, not from its printed script. 
that, the literary script by Milan Jariš and Vladimír Bor for this particular film, prescribes explicitly in its very first scene:

"Scene 1. Kitchen of a working-class flat [...]

Sounding into darkness in typical pauses are the familiar opening harp chords from Smetana's Vyšehrad: the Prague radio signature tune. It is repeated. And again, for the third time, the same sound of the legendary prophetic harps. Then, still into dark, comes the voice: - Attention! All stay tuned. We shall presently be broadcasting an important announcement. - The speaker of a D.I.Y. wireless set once again emits the Prague radio signature tune. [...] The radio signature tune seems to suggest an atmosphere of tension and to attract concentrated attention.

Scene 2. Industrial bakery workshop [...]

The P.A. system speaker hung on the wall attracts the eyes of all the workers present in the shop on that evening.

Jarda, a wiry athlete, was just working at the electric dough mixer. Drawn by the monotonous sounds of the radio signature tune, as though physically attracted, he approaches the speaker. On his way he unwittingly unties his white baker's apron. [...] The signature tune continues to heighten the suspense of waiting, the tension of a critical moment.

Scene 3. In front of a block of flats in Prague's Žižkov quarter [...]

Like hypnotized, a small bundle of people gathered beneath an open window on the ground floor of the block of flats, gaze at the window out of which issue the amplified sounds of the radio signature tune.

At last the signature tune fades to make way for an announcement: - The President of the Republic, acting in accord with the provisions of Paragraph 23 of the Defence Act, has decreed the mobilization of the Czechoslovak Armed Forces...

The bundle of people, who upon hearing the first words of the announcement have appeared to make an unwitting move towards the window, as though to absorb each word, shakes in a wave of excitement upon the utterance of the crucial sentence, breathing out as one mouth, one heart.

Music enters as the film's overture, in a grand upsurge, to apotheose the nation's patriotic valour." ${ }^{26}$

In the early 1970s, the atmosphere surrounding the Munich Agreement was taken up again by Otakar Vávra, in his film, Dny zrady [Days of Betrayal], the first part of the trilogy drawing on recent history, Dny zrady (1973); Sokolovo

${ }^{26}$ Milan Jariš and Vladimír Bor, Neporažení. Literary script - mimeograph (Prague, 1955), 1-3 (kept in the National Film Archive library, sign. S-108-LS). 
(1974); and Osvobozeni Praby [The Liberation of Prague] (1976), with which the protagonist of Czech cinematography reasserted, after the Soviet-led invasion of Czechoslovakia, for the next two decades his status as the regime's most coveted film director. For its part, Dny zrady, which Otakar Vávra himself has characterized as "documentary drama" 27 , or elsewhere, as "artistic documentary," 28 shares more than a few traits with Uloupená hranice. For one thing, both films' scripts were supplied by the same writer, Miloslav Fábera, plus, even the title of the film - "Days of Betrayal" - was the original working name of Uloupená hranice. Vávra's "re-enactment" depicts, on one plane, the world of high politics peopled by historical figures, and on another, the world of ordinary people, represented by fictional characters whose lives in that historical period are captured through the prism of individual stories. Of course, Vávra, as a filmmaker honouring conventions and stereotypes, could not possibly leave out the Smetana signature tune. It is featured, characteristically enough, in a scene where a patriotically-minded Czech family sit in their home kitchen, glued to the wireless set waiting for the declaration at any moment now of full-scale mobilization. The parents are joined at home by their two younger sons (the one of them who has already come of age cannot wait to be enlisted to defend the country, whereas the junior one had best join up too, but not being entitled he at least intones on the harmonica the traditional conscripts song, $V$ Hodonině za vojácka). There, the course of major historical events weighs down on the private world of a specific family: while the wireless set sends out recurrently, in short intervals, the Vyšehrad motive, alternating with the announcer's solemn voice inviting the listeners to stay tuned and wait for the broadcast of an item of great importance, the father finally musters the courage to tell the rest of the family that their third son, a finance guard officer, was killed on the border. The ensuing scene of mobilization is accompanied by the tones of Smetana's symphonic poem Tábor, and through it, echoes of the Hussite, chant Ktožjsú boži bojounici [Ye Who are Warriors of God].

A similar pattern is followed in František Filip's five-part television series Byl jednou jeden dìm [Once upon a Time There Was a House] (1974), after the script from Jan Otčenášek and Oldřich Daněk. The series is centered around the fates of tenants of a block of flats in Prague's working-class district of Žižkov, from the end of the first Czechoslovak Republic sometime in 1937 or 1938, through the Prague uprising in May 1945. The events around the Munich Agreement are dealt with in the series' second part, entitled Bio Ilusion: there, too, the wireless set is assigned the part of liaison between the private world and the world

${ }^{27}$ Cf.: Otakar Vávra, Podivný život režiséra. Obrazy vzpominek (Prague: Prostor, 1996), 269-271.

${ }^{28}$ This in fact is the subtitle common to the scripts of all three parts of Vávra's recent history trilogy, Dny zrady, Sokolovo, and Osvobozeni Prahy. 
of history at large, and the Smetana radio signature tune is likewise brought in, albeit not in reference to the mobilization, but rather to signal a step in the opposite direction, namely, the subsequent demobilization and the announcement of the Czechoslovak government's bowing to the conditions imposed on them by the Munich diktat. The sounds of the Vyšehrad harp motive serve as the backdrop for a visual tour of the block's individual households: families of petrified, shattered tenants, individuals from various walks of life, of different vocations, contrasting political outlooks, yet sharing the same home, in terms of both country and house. (One of them, Drvota, a forwarding agent, boosted by an overdose of alcohol, succumbs to the weight of the moment and hurls the wireless set onto the floor, punishing the medium as the messenger of bad news.)

The Smetana radio signature tune was also used by Jiří Sequens, in arguably his finest opus, Atentát [Assassination] (1964), a re-enactment of the assassination in May 1942 of Nazi Reichsprotektor Reinhard Heydrich. The signature tune can be heard in a scene where the company of paratroopers who carried out the assassination, in hiding at a private flat, listen in to the Prague Radio's official announcement of the attempt on Heydrich's life. The Smetana harp motive comes only after the news has been aired, whereupon it is repeated several times. It is thus once again correlated firmly with a particular dramatic event, and implicitly also with the massive wave of repression in its aftermath. Though the period around the assassination of Heydrich has been treated in quite a few films, and the motive of radio broadcast is present in virtually all of them, surprisingly enough the linkage of the subject with the signature tune is rather exceptional. In its place, these films have adopted as the radio broadcast sonic convention the monotonous roll call of the names of freshly executed persons.

In what has likewise become a tradition, the signature tune has been reserved a slot in cinematic portrayals of the Prague uprising in May 1945. The memorable Prague radio appeal for help has come to rank among the truly obligatory sequences in films dealing with this event, and has been coupled inseparably with the signature tune ever since the time of the first treatment of those turbulent days of May in a feature film, Otakar Vávra's Némá barikáda [The Silent Roadblock] (1949). The way in which the radio broadcast is welded together with the structure of the plot has in fact followed a single model, repeated over and over again: namely, the Czechoslovak Radio calls, intertwined with the signature tune, boost the protagonists' determination to engage in resistance, or are used as background to scenes of resistance action, symbolizing the people's uprising. This applies not only to the already mentioned Némá barikáda, but also to Osvobozeni Praby (1976) from the same director, in Ivo Novák's screen drama, Maratón [Marathon Run] (1968), and in the television series, Byl jednou jeden 
dìm, where it features in its final, fifth part entitled Obvaziště Boccaccio [Dressing Station Boccaccio].

That last instance is a model case: in it, the mercurial forwarding agent Drvota, whom we witnessed earlier on, in the series' Part Two, taking in the news of the acceptance of the Munich diktat, blasts into the yard of the block of flats with shouts of "turn on the radio!", and rouses the whole house with frantic banging on a suspended steel rail. The radio broadcasts repeated calls to the Czech populace, interspersed with the tones of the Smetana signature tune, to come and defend the radio headquarters. However, the films listed above also involve certain concepts which happen to be more elaborately structured than that. Thus the composer of music for Osvobozeni Praby, Zdeněk Liška, employed the signature tune as autonomous film music which, overlaid sonically by the noise track, accompanies all of the movie's scenes reenacting the street fighting around the radio headquarters. That what one hears there is not the signature tune being aired on the radio at that particular moment was signalled by the composer through speeding up somewhat the two-bar motive's tempo, and having it repeated mechanically, without the standard broadcasting practice pauses. For its part, Ivo Novák's Maratón, based on the script from Jan Procházka, exemplifies another type of semantic condensation: there, the sounds of the Smetana signature tune playing on the radio are used as a backdrop to, among others, a scene of mob violence on a German or collaborator. This is actually a reenactment of a surviving documentary shot from the May of 1945. In it, a large group of participants in the Prague uprising flag down a vehicle on the road, overturn it, and haul from under the car a terrified man who ends up severely beaten. (In the scene's feature-film version, the man is killed by a hail of shots from the machine-gun of a German fighter that is flying over the district at the moment and sprays the street with several rounds of gunfire.) The coupling of the Smetana signature tune with the image of "vigilante" violence was, in the context of the debate going on in this country in the late 1960s, doubtless aimed at contesting the myths in which the country's modern history was then being enshrouded, an approach which after all corresponded with the film's obvious ambition to view the Prague uprising from a private viewpoint: as an utterly confused sequence of diverse street scenes, occasionally involving thoroughly unwarranted loss of life. In more than a few respects, Procházka's and Novák's approach to the Prague uprising resembles that assumed somewhat later on by Jiři Kovtun, in his demythologizing story, Pražská ekloga [The Prague Eclogue] (1973).

In recent years, the long-established convention was challenged by David Ondřiček, a representative of the generation of filmmakers that entered the scene in the 1990s, to contribute a crucial share in the shaping of Czech cinema 
after the downfall of communism and the demise of the state monopoly on film production. It happenned in the film, Samotári [Loners] (1999), which has since earned a cult status, to the script of Petr Zelenka and Olga Dabrowská. The movie offers a tragicomical, grotesquely eccentric portrayal of the young generation, set the in present-day Prague and exposing as its principal theme problems arising in interpersonal communication, frustration caused by feelings of alienation, and a kind of fatal aimlessness and absence of purpose in life. Ondříček's bitter comedy derives its style from that of the "independent cinema", a movement which has by design contrasted itself, as regards both thematic range, genre, script, style and production, with the cinematic mainstream, and has engaged in a search for alternative concepts. In tackling cinematic conventions and stereotypes, it often chooses to recycle them, set them into unorthodox contexts, drawing from the resultant "deviations" a comic, bizarre, or shocking effect. There, Ondříček used the radio's musical emblem in a bizarre scene of a simulated wait for an UFO. This is a night sequence climaxing in a take which mockingly evokes the landing of an extra-terrestrial spaceship. The camera's lens aims straight into the dazzling headlights of an automobile, in front of which towers the comic "spectral" figure of Jakub, a young man taking everyday recourse to marijuana as a means of keeping relaxedly detached and somewhat out of the ordinary. The fluorescing car emits a cacophony of musical "SF" sounds which suddenly give way, in an absurdly contrasting switch, to the tones of the Smetana signature tune. On the musical plane, this contrast sets up tension between synthetic and acoustic sources of tones, whereas on the semantic plane, tension between the "cosmic" and the terrestrially local. Thus, on the territory of independent cinema, the Smetana signature tune finds itself released from the web of its political and historical connotations, instead returning to its original localizing function. Of course, this return is not quite complete: in the underlying semantic depths of the symbol, such connotational relation cannot be deleted automatically, something the makers of that film were most definitely well aware of. This seems to be evidenced by their enjoyment of having a go at yet another hypertrophied musical emblem: namely, the national anthem. It can be heard here coming out of a turned-on television set at the home of a drug trafficker, just as Jakub enters to buy a fresh supply of the indispensable "grass."
Jakub: $\quad$ Awesome pad. - (The tv screen shows Czech athletes stepping up onto the winners platform to the tones of the national anthem. The drug trafficker steps up to the set to switch it off.) Don't turn it off. Awesome tune. What is it?

Trafficker (incredulously): The national anthem, bonehead. 
Jakub: Oh, yeah. I haven't heard the instrumental version lately, so I forgot it.

To be sure, Ondříček's Samotári is an utterly isolated exceptional case. The recurrent use of the Smetana radio signature tune in similar film scenes turns us to witnesses of the birth of a stereotype. A wireless set with this signature tune on becomes an "emblem" of certain well known dramatic events of modern Czech history; as a result, the Vyšehrad motive's ponderous history-related semantics set in the context of radio broadcast then markedly narrows the scope of its potential use in other, more "natural" or more "normal" contexts, which in its turn by no means rules out its parodic use (rather on the contrary, tending to provoke it). That notwithstanding, the convention described here and documented by numerous examples entails a peculiar side-effect, consisting in that, ironically enough, the stereotyped symbolic practice of Czech feature film production shifts the Smetana radio signature tune from the mode of everyday reality back to the mode of holiday solemnity, in terms of the exceptional import of a historic moment heralded by the signature tune. It should not be forgotten that the process of emblematization of historical events of the years 1938-1945 was initiated outside the territory of cinematic fiction, in the actual reception of day-to-day reality during the drama-laden summer and autumn of the year 1938. 


\section{APPENDIX}

Characteristic Radio Signature Tunes

BELLS AND GLOCKENSPIEL:

Augsburg: 5 bell chimes (see Munich)

Basel: four-note glockenspiel

Barcelona: 12:00 noon and 10:00 p.m. cathedral bells

Bratislava: four-note glockenspiel

Aachen: ringing (see Langenberg)

Zurich: 7:00 p.m. (Saturday), church bells

Freiburg: common chord

Innsbruck: gong beats

Kaiserslautern: 5 bell chimes (see Munich)

Kalundborg: 12:00 noon, 6:00 p.m., 10:00 p.m. and 12:00 midnight, Copenhagen Town Hall Carillon (see Copenhagen), or gong

Copenhagen: 12:00 noon, 6:00 p.m., 10:00 p.m. and 12:00 midnight, Town Hall Carillon, topped off by three gong beats

Cologne: ringing (see Langenberg)

Košice: 7:00 p.m. (Sunday), tower clock chimes and bells

Langenberg: ringing

Leningrad: gong (cuckoo sounds)

London: chimes of Big Ben

Madrid: 12:00 noon, 8:00 p.m., 11:00 p.m. and 1:00 a.m., Government House Carillon

Munich: 11:00 a.m., Town Hall Bells; five bell chimes

Münster: ringing (see Langenberg)

Nuremberg: five bell chimes (see Munich)

Budapest: glockenspiel (9 notes, E major)

Prague: 7:00 p.m. and 11:00 p.m., St Ludmila's tower clock

Rome: bell chimes

Istanbul: 75 gong beats spaced at one-second intervals

Istanbul: gong (75 p.m.)

Stockholm: 6:00 p.m. (Sunday), Town Hall Carillon

Strasbourg PTT: deep-tone ringing

Toulouse: high-tone ringing

Tallinn: gong and announcement, "Tallinn"

Warsaw: 8:00 p.m., clock chimes

\section{ALARM CLOCKS AND PENDULUMS}

Angora: ticking (200 p.m.)

Berlin: ticking (4 p.sec.)

Berne: slow-paced ticking

Bucharest: ticking (160)

Klagenfurt: chronometre 
Daventry: alarm clock

Dresden: alarm clock

Frankfurt: alarm clock

Gdańsk: alarm clock

Gliwitz: pendulum (see Frankfurt)

Kassel: alarm clock (see Frankfurt)

Königwusterhausen: alarm clock (see Berlin)

Linz: alarm clock (see Vienna)

Leipzig: alarm clock (270 p.m.)

London: alarm clock

Luxembourg: loud ticking

Poznań: alarm clock (occasionally)

Riga: alarm clock

Graz: ticking (200)

Vienna: alarm clock (270 p.m.)

Wroclaw: pendulum

Zagreb: alarm clock (100 p.m.)

\section{MELODIES}

Barcelona: traditional ( $\mathrm{F}$ major)

Zurich: A flat-A flat-C-C.

Dresden: see Leipzig

Freiburg: D-E-A

Grenoble: yodelling

Heilsberg: see Königsberg

Huizen: G-D-E-B-D-B

Genoa: flute tune

Königsberg: three times D flat and A flat

Cracow: E-D-B flat

Leipzig: B flat-A-C-B (B.A.C.H.)

Naples: flute tune

Madrid: French horn tune

Mühlacker: see Stuttgart

Sottens (Suisse Romande): two-voice motive in C major

Stuttgart: D-E-A

Warsaw: two-voice piano tune

\section{WIND SIGNATURES AND BUZZERS}

Bremen: -...--- (Morse code: BMN)

Brussels: drawn whistle (prior to broadcast)

Flensburg: telegraph code

Geneva: whistle (prior to broadcast)

Hamburg: ......- (HA)

Hanover: ......-. (HR) 
Kiel: -.-.-. (KL)

Cracow: 12:00 noon and 10:00 p.m., fanfares from St Mary Magdalen's Church

Madrid: French horn tune

Milan: deep-toned buzz spaced at seven-second intervals

Naples: flute tune

Poznań: Town Hall Tower fanfare

Prague: -..... (time signal)

Warsaw: fanfare (see Cracow)

Vilnius: fanfare (see Cracow)

\section{BIRDSONG}

Genoa: nightingale song

Leningrad: cuckoo (plus gong)

Lyons: canary song

Milan: nightingale song

Palermo: nightingale song

Strasbourg: cuckoo

Turin: canary song

Toulouse: chirping

Vilnius: cuckoo

Ljubljana: cuckoo

\section{MISCELLANEOUS}

Katowice: hammer blow

Radio-journal 10, no. 45 (November 5, 1932): back sleeve. 


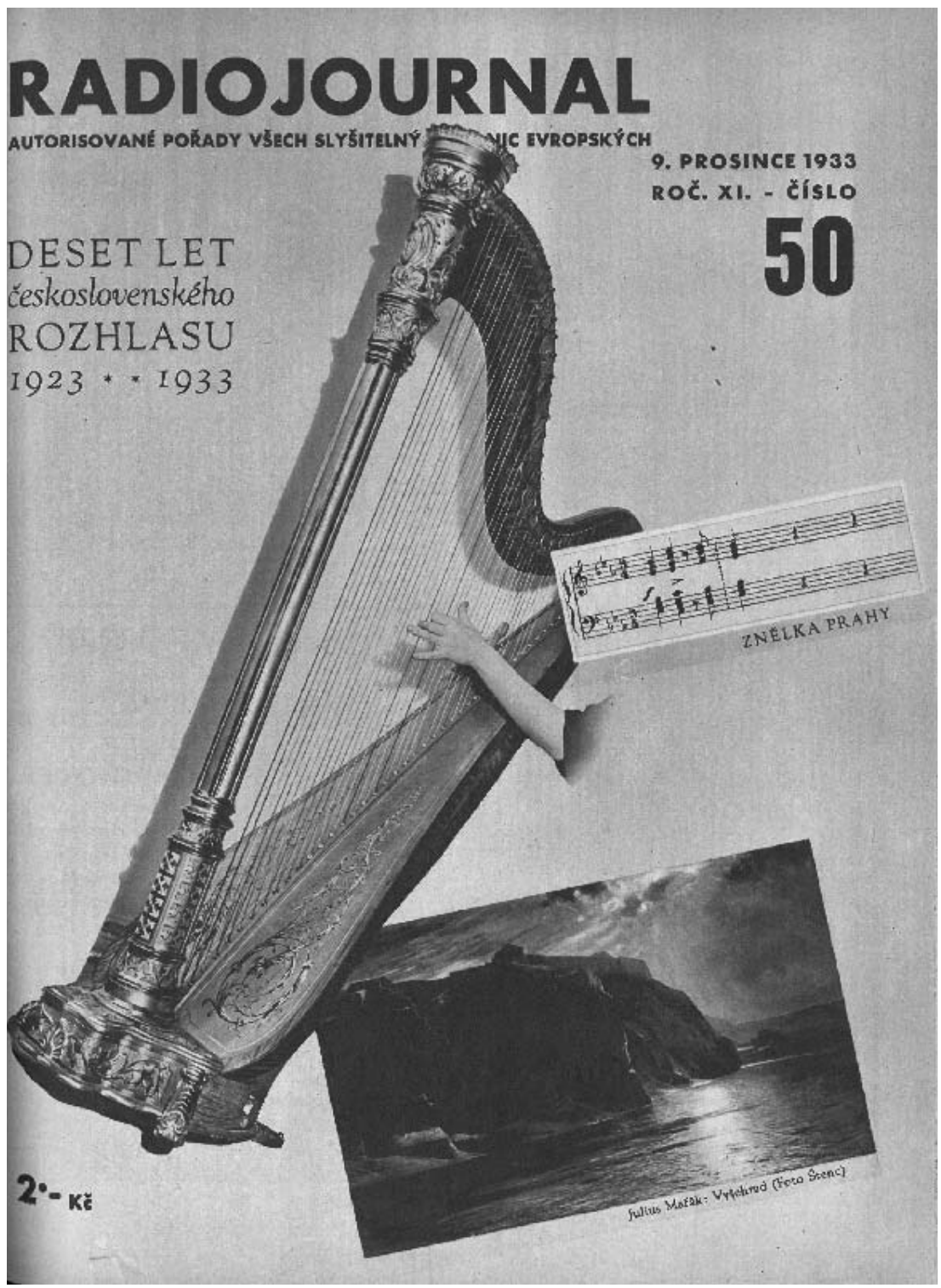

Cover of the radio magazine Radiojournal from 9 December 1933 promoting radio Praha's new jingle - the introductory two-bar Vyšehrad harp motive from the symphonic poem of the same name by Bedřich Smetana. 


\title{
The Motive of Vyšehrad as a Wireless Signature Tune on the Waves of Praha Radio Station and in Feature Films
}

\begin{abstract}
The opening bars of Smetana's symphonic poem Vyšehrad found "a new life" in the form of a signature tune on the radio station Praha used since 1933. Radio signature tunes are often inspired by famous works that have the potential to represent a certain cultural circle (such as Leipzig and the tones $\mathrm{B} b-\mathrm{A}-\mathrm{C}-\mathrm{B}$ ). It is a music emblem that is easy to remember and has been entering various contexts, particularly thanks to sound in film, in the form of a memento (for instance the Munich Agreement of 1938 or the war events) as well as by means of high explanatory power revealing actors' attitudes, creating comic situations, etc.
\end{abstract}

\section{Motiv ze symfonické básně Vyšehrad jako znělka na vlnách rozhlasu Praha a na filmovém plátně}

\section{Abstrakt}

Úvodní takty Smetanovy symfonické básně Vyšehrad začaly žít ,jiný život“ v podobě znělky rozhlasové stanice Praby od roku 1933. Rozhlasové znělky jsou často inspirovány známými díly, které v sobě nesou potenciál reprezentovat určitý kulturní okruh (např. Lipsko a tóny B-A-C-H). Dobře zapamatovatelný hudební emblém vstupoval a stále vstupuje zejména díky zvukovému filmu do nejrůznějších kontextů jak v podobě mementa (např. Mnichovská dohoda z roku 1938, válečné události), tak jako prostředek s vysokou výpovědní hodnotou, prozrazující mínění aktérů, navozující komické situace apod.

\section{Keywords}

Bedřich Smetana; symphonic poem Vyšehrad; radio

\section{Klíčová slova}

Bedřich Smetana; symfonická báseň Vyšehrad; rozhlas 
The Motive of Vyšehrad as a Wireless Signature Tune on the Waves of Praha Radio Station and in Feature Films

Ivan Klimeš

Katedra filmových studií

Filozofická fakulta

Univerzita Karlova

nám. Jana Palacha 2

11638 Praha 1, Česká republika

ivan.klimes@ff.cuni.cz 